\title{
RANCANG BANGUN SISTEM PEMBELIAN BAHAN BAKU PADA CV MEDIA KARYA
}

\author{
Sri Rodziyah, Sarana, Nikmatuniayah, \\ Politeknik Negeri Semarang. Jl. Prof. Soedarto,S.H, Tembalang, Semarang \\ 50275
}

\begin{abstract}
Abstrak: Tujuan penelitian ini adalah untuk membuat rancang bangun sistem informasi pembelian bahan baku pada CV Media Karya untuk mempermudah pengelolaan pembelian. Penelitian ini menggunakan data primer dan data sekunder berupa data kuantitatif dan data kualitatif.Teknik pengumpulan data yang digunakan adalah observasi, wawancara dan studi pustaka. Sistem pembelian bahan baku ini dibuat dengan menggunakan Microsoft Visual Basic 6.0 sedangkan penyimpanan database menggunakan Microsoft Acces dan Crystal Report 8.5 untuk menghasilkan laporan. Metode pengembangan yang digunakan adalah SDLC (System Development Life Cycle). Aplikasi sistem pembelian bahan baku ini dapat mengatasi masalah yang terdapat pada CV Media karya mengenai sistem pembelian bahan baku dan dapat memberikan pengingat stok dalam penggunaan bahan baku. Data masukan pada aplikasi ini adalah data pemasok, data jenis bahan, saldo awal persediaan, pembelian dan pemakaian bahan baku. Aplikasi ini menghasilkan laporan pembelian, laporan data pemasok, laporan data utang, laporan bahan baku dan laporan mutasi persediaan.
\end{abstract}

Kata kunci: SDLC (System Development Life Cycle), Pembelian dan Bahan Baku.

Abstract: The purpose of this study is to create a design system for purchasing raw material information at CV Media Karya to facilitate the management of purchases. This study uses primary data and secondary data in the form of quantitative data and qualitative data. Data collection techniques used are observation, interviews and literature. This raw material purchasing system is made using Microsoft Visual Basic 6.0 while database storage uses Microsoft Access and Crystal Report 8.5 to generate reports. The development method used is SDLC (System Development Life Cycle). This raw material purchasing system application can overcome the problems found in CV Media's work on the raw material purchasing system and can provide a reminder of the stock in the use of raw materials. Input data in this application are supplier data, material type data, initial inventory balance, purchase and use of raw materials. This application generates purchase reports, supplier data reports, debt data reports, raw material reports and inventory mutation reports.

Keywords: SDLC (System Development Life Cycle), Purchases and Raw Materials. 


\section{PENDAHULUAN \\ Latar Belakang}

Indonesia sudah menapaki era revolusi industri 4.0, yang dapat ditandai dengan serba digitalisasi dan otomasi.Pada era ini, memungkinkan terjadi peningkatan yang signifikan dalam penggunaan teknologi di sektor pekerjaan tak terkecuali pada bidang bisnis.Penggunaan teknologi pada pelaku bisnis bertujuan untuk mendapatkan keuntungan dari segi minimalisasi biaya dan efisiensi waktu.Selain itu, penggunaan teknologi tepat guna dapat membantu pengambilan keputusan yang cepat, tepat, dan akurat agar hasil yang diharapkan mampu optimal. Kelebihan lain yang perlu dipertimbangkan yaitu dapat meminimalisir kesalahankesalahan yang diakibatkan oleh human error.

Usaha Mikro, Kecil dan Menengah (UMKM) adalah tulang punggung ekonomi di Indonesia. UKM sangat penting bagi Indonesia karena dapat menyumbang $\quad 60 \% \quad$ Pendapatan Domestik Bruto (PDB) dan menampung $97 \%$ tenaga kerja (www.kemenkeu.go.id, 29/08/2016). UKM dapat menopang laju pertumbuhan ekonomi dan menjadi katup penyelamat pemulihan ekonomi nasional.CV Media Karya berdiri sejak tahun 2001, beralamatkan di Jalan Zebra Tengah III No. 53, Pedurungan, Semarang. Perusahaan ini merupakan usaha kecil menengah (UKM) di kota Semarang yang bergerak pada bidang usaha jasa pengadaan barang, LPK jahit dan konveksi. Kegiatan bisnis pada bidang usaha konveksi adalah membuat dan menjual produk sandang kepada instansi pemerintahan, swasta dan masyakat umum, seperti seragam sekolah, karate maupun kantor, jaket, kemeja, kaos polo, umbul-umbul, tas dan masih banyak lagi. UKM ini terus berkembang dan banyak menjalin kerjasama dengan berbagai instansi seperti Dinas/Badan Lingkungan
Hidup, FORKI, Suara Merdeka, Kompas, Tribun Jateng, dan lain-lain. Kegiatan usaha CV Media karya adalah penjualan berbasis pesanan. Setiap bulan CV Media Karya menerima kurang lebih 150 pesanan, namun apabila terdapat event-event di Kota Semarang maka pesanan akan meningkat cukup banyak. Pembelian merupaka aktifitas yang penting dalam menunjang kegiatan operasional perusahaan.

Pencatatan transaksi yang dilakukan pada CV Media Karya masih menggunakan pencatatan berbasis manual, hal tersebut menyebabkan kesalahan pencatatan transaksi pembelian yang diakibatkan oleh human error. Cara pencatatan ini kurang memadai dan bisa menyita waktu dan menyebabkan keterlambatan jika ingin menyajikan laporan yang dibutuhkan perusahaan dalam waktu singkat. Sistem informasi pembelian bahan baku secara terkomputerisasi diperlukan oleh CV Media Karya untuk mempermudah dalam menjalankan kegiatan bisnis. Berdasarkan permasalahan tersebut, maka perlu dibuat rancang bangun sistem informasi pembelian bahan baku pada CV Media Karya.

\section{Rumusan Masalah}

Dari permasalahan tersebut maka rumusan masalah yang dapat diambil adalah bagaimana merancang dan membangun sistem informasi pembelian pada CV Media Karya?

Pembatasan masalah dilakukan untuk memberikan arah dan tujuan yang jelas dalam penelitian ini, karena mengingat luasnya permasalahan yang berkaitan dengan sistem pembelian bahan baku pada CV Media Karya yang menerapkan sistem produksi berdasarkan pesanan, maka batasan masalahnya mencakup hal berikut:

1. Sistem informasi ini hanya meliputi sistem informasi pembelian bahan baku pada CV Media Karya. 
2. Tidak dibahas mengenai pengeloalaan pembelian secara tunai, karena pembelian bahan baku dilakukan secara kredit.

3. Terdapat data penggunaan atau pemakaian bahan baku untuk mengetahui jumlah bahan baku yang digunakan untuk setiap pesanan.

\section{Pengertian Sistem}

Sistem adalah serangkaian dua atau lebih komponen yang saling terkait dan berinteraksi untuk mencapai tujuan.Sebagian sistem terdiri dari subsistem yang lebih kecil yang mendukung sistem yang besar (Romney, 2015:3). Menurut West Chruchman (dalam Krismiaji,2010:1) Sistem adalah serangkaian komponen yang dikoordinasikan untuk mencapai serangkaian tujuan. Dapat disimpulkan bahwa sistem merupakan serangkaian komponen yang saling berhubungan antara satu dengan lainnya dan memiliki suatu tujuan yang sama.

\section{Pengertian Informasi}

"Informasi adalah data yang diolah menjadi bentuk yang lebih berguna dan lebih berarti bagi yang menerimanya" (Puspitawati dan Anggadini, 2011:13). 6 Sedangkan menurut Romney (2015:4) Informasi (information) adalah data yang telah dikelola dan diproses untuk memberikan arti dan memperbaiki proses pengambilan keputusan. Dapat disimpulkan bahwa informasi adalah data yang telah diolah sehingga bermanfaat dalam proses pengambilan suatu keputusan.

\section{Pengertian Sistem Informasi}

Sistem informasi kadang disebut sebagai sistem pemrosesan data, merupakan sistem buatan manusia yang biasanya terdiri dari sekumpulan komponen baik manual maupun berbasis komputer yang terintegrasi untuk mengumpulkan, menyimpan, dan mengelola data serta menyediakan informasi kepada pihak-pihak yang berkepentingan sebagai pemakai informasi tersebut (Diana dan Setiawati: 2011:4).

\section{Komponen Sistem Informasi}

Menurut Mulyadi (2016:8) setiap sistem informasi terdiri dari blok-blok bangunan yang membentuk sistem tersebut. Komponen bangunan sistem informasi yang terdiri dari enam blok: masukan, model, keluaran, teknologi, basis data, dan pengendalian. Berikut ini diuraikan pengertian setiap blok bangunan sistem informasi tersebut.

a. Blok masukan

Masukan adalah data yang dimasukkan ke dalam sistem informasi beserta metode dan media yang digunakan untuk menangkap dan memasukkan data tersebut ke dalam sistem.Masukan terdiri dari transaksi, permintaan, penyertaan, perintah dan pesan.

b. Blok model

Blok model terdiri dari logicomathematical models yang mengolah masukan data yang disimpan, dengan berbagai macam cara, untuk memproduksi hasil yang dikehendaki atau keluaran. Logico-mathematical models dapat mengkombinasi unsurunsur data yangmenyediakan jawaban atas suatu pertanyaan, atau dapat meringkas atau menggabungkan data menjadi suatu laporan ringkas.

c. Blok keluaran

Produk suatu sistem informasi adalah keluaran yang berupa informasi yang bermutu dan dokumen untuk semua tingkat manajemen dan semua pemakai luar organisasi.

d. Blok teknologi

Teknologi ibarat mesin utuk menjalankan sistem informasi. Teknologi menangkap masukkan, menjalankan model, menyimpan dan mengakses data, menghasilkan dan menyampaikan keluaran, serta mengedalikan seluruh sistem. Dalam sistem informasi berbasis komputer, 
teknologi terdiri dari tiga komponen: komputer dan data penyimpanan dari luar (auxiliary storage), telekomunikasi, dan perangkat lunak (software).

e. Blok basis data

Basis data merupakan tempat untuk menyimpan data yang digunakan untuk melayani kebutuhan pemakai informasi.Basis data dapat diperlakukan dari dua sudut pandang, secara fisik dan logis.Basis data secra fisik berupa media untuk menyimpan.Basis data secara logis menyangkut bagaimana struktur penyimpanan data sehingga menjamin ketepatan, ketelitian dan relevansi pengambilan informasi untuk memenuhi kebutuhan pemakai.

f. Blok kendali

Semua sistem informasi harus dilindungi dari bencana alam, api, kecurangan, kegagalan sistem, kesalahan dan penggelapan, ketidakefisienan, sabotase, dan orangorang yang dibayar untuk melakukan.

\section{Pengertian Sistem Informasi Akuntansi}

Sistem informasi akuntansi adalah suatu sistem yang berfungsi untuk mengorganisir formulir, catatan dan laporan yang dikoordinasi untuk mengasilkan informasi keuangan yang dapat digunakan sebagai bahan pengambilan keputusan manajemen dan pimpinan serta mempermudah pengelolaan perusahaan (Puspitawati dan Anggadini, 2011:57). Menurut Krismiaji (2010:4) Sistem informasi akuntansi adalah sebuah sistem yang memproses data dan transaksi guna menghasilkan informasi yang bermanfaat untuk merencanakan, mengendalikan, dan mengoperasikan bisnis. Sedangkan menurut TMBooks (2015:1) Sistem Informasi Akuntansi (SIA), merupakan sistem yang menyediakan informasi akuntansi dan keuangan beserta informasi lainnya yang diperoleh dari proses rutin transaksi akuntansi. Informasi yang dihasilkan SIA meliputi informasi tentang order penjualan, penjualan, peneriman kas order pembelian, penerimaan barang, pembayaran dan penggajian. Dapat disimpulkan bahwa sistem informasi akuntansi adalah sistem yang mengolah data dan transaksi perusahaan untuk menghasilkan informasi akuntansi dan keuangan guna mempermudah pembuatan keputusan oleh manajemen dan pimpinan.

Berdasarkan definisi tersebut sistem informasi akuntansi terdiri dari tiga komponen utama, ketiga komponen tersebut adalah input, proses dan output. Fungsi ini menunjukkan bahwa sistem sebagai proses tidak dapat berdiri sendiri, melainkan harus terdapat input, proses dan output. Input merupakan segala sesuatu yang masuk ke dalam suatu sistem dan sebagai pemicu bagi sistem untuk melakukan proses. Proses merupakan perubahan input menjadi output. Proses dapat berupa perakitan yang disusun berdasarkan aturan tertentu. Output adalah hasil dari suatu proses yang merupakan tujuan dari sistem tersebut.

\section{Sistem Informasi Akuntansi Pembelian}

Pengadaan suatu barang yang dibutuhkan perusahaan dapat dipenuhi dengan cara pembelian. Pembelian menurut sifat pembayarannya dapat digolongkan menjadi dua, yaitu pembelian kredit dan pembelian tunai. Secara garis besar transaksi pembelian mencakup prosedur berikut (Mulyadi, 2016:244):

1. Fungsi gudang mengajukan permintaan pembelian ke fungsi pembelian menyimpan barang yang telah diterima oleh fungsi penerimaan.

2. Fungsi pembelian meminta penawaran harga dari berbagai pemasok. 
3. Fungsi pembelian menerima penawaran harga dari pemasok dan memilih pemasok.

4. Fungsi pembelian membuat order pembelian kepada pemasok yang dipilih.

5. Fungsi penerimaan memeriksa jenis, mutu dan kuantitas barang yang diterima dari pemasok untuk menentukan apakah barang tersebut dapat diterima atau tidak oleh perusahaan. Fungsi ini juga menerima barang dari pembeli yang berasal dari transaksi retur penjualan.

6. Fungsi penerimaan menyerahkan barang yang diterima kepada fungsi gudang untuk disimpan.

7. Fungsi penerimaan melaporkan penerimaan barang kepada fungsi akuntansi.

8. Fungsi akuntansi menerima faktur tagihan dari pemasok dan atas dasar faktur dari pemasok tersebut, fungsi akuntansi mencatat kewajiban yang timbul dari transaksi pembelian.

\section{Dokumen yang Digunakan}

Kualitas informasi yang dihasilkan dari sistem pembelian dilihat berdasarkan sumber dokumen yang digunakan dalam proses pencatatannya. Pada umumnya dokumen yang digunakan dalam sistem pembelian memuat kelengkapan dari permintaan barang sampai dengan bukti bahwa barang telah diterima. Dokumen yang digunakan dalam sistem pembelian menurut Mulyadi (2016:246) adalah sebagai berikut:

1. Surat permintaan pembelian

2. Surat permintaan penawaran harga

3. Surat order pembelian

4. Laporan penerimaan barang

5. Surat perubahan order pembelian

6. Bukti kas keluar

\section{File yang Digunakan dalam Sistem} Informasi Akuntansi Pembelian

Catatan akuntansi yang digunakan dalam sistem informasi akuntansi pembelian berbasis komputer menurut Krismiaji (2010:353) adalah sebagai berikut:

1. File Induk

File induk adalah file utama yang digunakan untuk menyimpan data dari suatu penginputan sistem informasi akuntansi. File induk terdiri dari file induk pemasok dan file induk persediaan.

2. File Transaksi

Jumlah file transaksi yang digunakan dalam siklus pengeluaran khususnya pembelian tergantung pada sistem yang digunakan oleh suatu entitas usaha,

\section{Laporan yang Dihasilkan}

Laporan yang dihasilkan dalam sistem akuntansi pembelian menurut Krismiaji (2010:349) adalah sebagai berikut:

1. Laporan Kontrol

Laporan ini merupakan ringkasan perubahan yang dilakukan terhadap sebuah file. Berisi informasi tentang transaksi yang telah diposting, jumlah angka atau nomor transaksi, dan daftar perubahan yang dibuat selama pemeliharaan file.

2. Laporan Khusus

Laporan ini membantu manajer dalam membuat jadwal pembayaran utang kepada pemasok.

3. Laporan Faktur dan Umur Voucher Laporan ini berisi daftar faktur pembelian yang belum dibayar pada tanggal laporan dan meringkas voucher menurut umurnya.

4. Laporan Kebutuhan Kas

Laporan ini meringkas faktur pembelian urut jatuh tempo.

\section{Bahan Baku}

Dalam perusahaan industri dibutuhkan bahan baku untuk dapat membuat suatu produk jadi maupun setengah jadi. Bahan baku merupakan 
bahan yang membentuk bagian integral dari produk jadi yang dimasukkan secara eksplisit dalam perhitungan biaya produk (Widilestariningtyas et al, 2012:3). Contoh dari bahan baku ialah kayu yang digunakan untuk membuat mebel, kain yang digunakan untuk membuat pakaian dan minyak mentah yang digunakan untuk membuat bensin.

\section{Metode Pengembangan Sistem}

Metodologi pengembangan sistem adalah langkah-langkah yang dilalui oleh analis sistem dalam mengembangkan sistem informasi (Mulyadi, 2016:31).

Sedangkan alasan-alasan dilakukannya perubahan terhadap sistem akuntansi suatu perusahaan menurut Krismiaji (2010:173) adalah sebagai berikut:

1. Perubahan kebutuhan pemakai atau perusahaan.

Meningkatnya kompetisi, pertumbuhan, konsolidasi, peraturan baru atau perubahan dalam pola hubungan regional atau global dapat mengubah sebuah struktur organisasi dan tujuannya.

2. Perubahan teknologi.

Apabila teknologi mengalami kemajuan dan lebih murah, maka sebuah organisasi dapat memperoleh suatu sistem yang lebih responsif terhadap kebutuhan informasi pemakai secara lebih efisien.

3. Perbaikan proses pengembangan bisnis.

Banyak perusahaan memiliki proses bisnis yang tidak efisien dan memerlukan pembaruan.

4. Dorongan untuk mempertahankan keuanggulan kompetitif.

Meningkatnya kualitas dan kuantitas serta kecepatan informasi dapat berakibat pada perbaikan produk atau jasa dan mungkin dapat menurunkan biaya.

5. Peningkatan produktivitas.

Komputer dapat mengotomatiskan sebagian besar pekerjaan klerikal dan berulang sehingga dapat meningkatkan produktivitas karyawan dan perusahaan.

6. Pertumbuhan perusahaan.

Pertumbuhan perusahaan mengakibatkan kebutuhan informasi berubah, dengan demikian sistem informasi yang dimiliki perusahaan harus diubah agar dapat menghasilkan informasi baru yang tepat.

7. Downsizing.

Perkembangan teknologi komputer yang cepat mendorong perusahaan untuk berpindah dari pengguna komputer besar (mainframe) ke komputer kecil ( PC dan jaringannya).

8. Perbaikan kualitas.

Perbaikan kualitas sulit dilaksanakan tanpa memperbaiki sistem yang menghasilkan informasi yang diperlukan untuk mengukur dan mengevaluasi kualitas.

Perubahan terhadap sistem informasi akuntansi dapat berupa perubahan kecil maupun perubahan menyeluruh sekaligus pembuatan sistem baru. Seberapapun besarnya perubahan terhadap sebuah sistem, upaya perbaikan yang dilakukan tetap melalui sebuah proses yang sama disebut daur hidup pembuatan sistem (Systems Development Life $C y c l e / S D L C)$, yang terdiri atas lima tahapan, yaitu analisis sistem, perancangan konseptual, perancangan fisik, implementasi dan konversi, serta operasi dan pemeliharaan. Pendekatan waterfall merupakan salah satu model pengembangan perangkat lunak SDLC. 


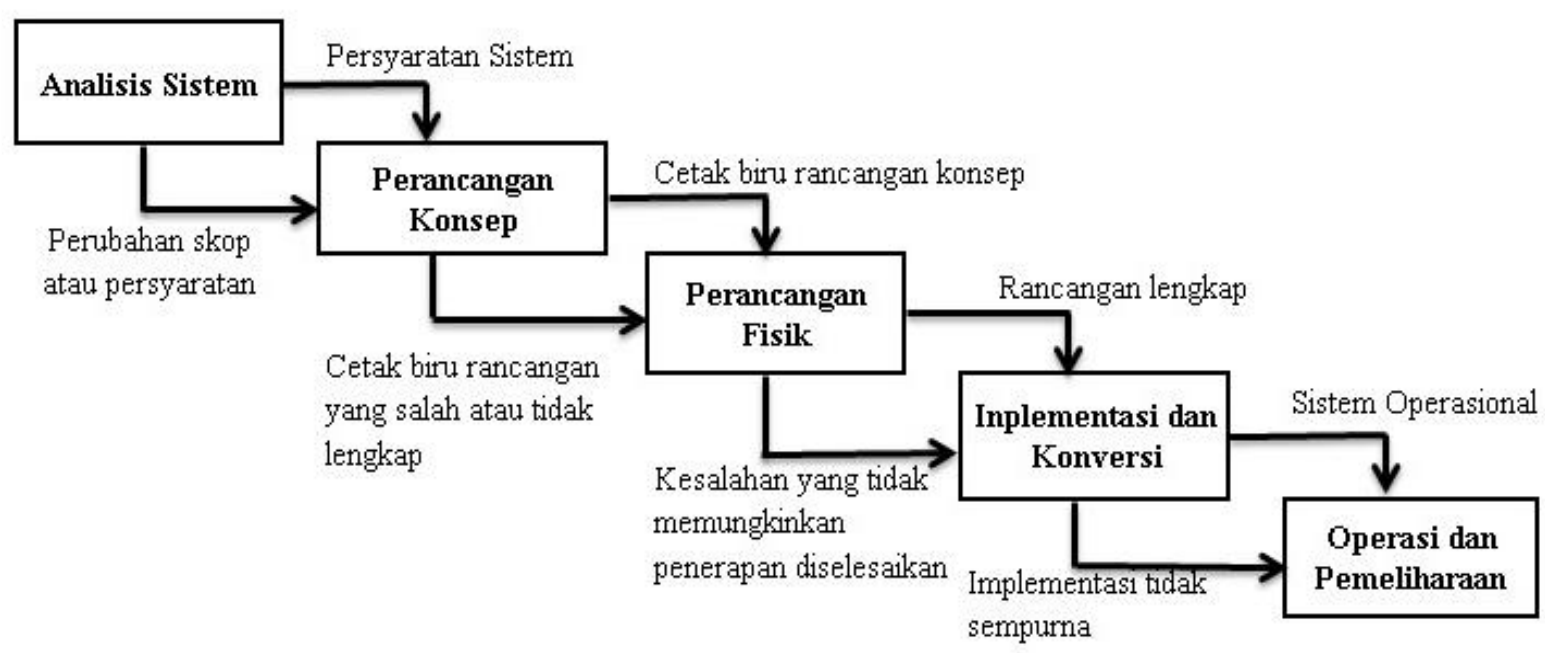

Gambar 2.3 Alasan Pengulangan Tahap Penyusunan Sistem Informasi

(Sumber Krismiaji, 2010:179)

Tahap-tahap siklus daur hidup sistem:

1. Analisis Sistem

Tahap analisis sistem merupakan tahapan yang paling awal, dilakukan pengidentifikasian masalah dengan mengumpulkan informasi mengenai masalah yang dihadapi oleh suatu perusahaan. Pada tahap ini terdapat lima aktivitas, yaitu:

a. Investigasi awal

Dilakukan untuk menyaring atau menyeleksi proyek.

b. Survei sistem

Dilakukan untuk memperoleh gambaran mengenai cara kerja sistem yang sedang digunakan.

c. Studi kelayakan

Menggunakan informasi yang diperoleh darisurvei sistem untuk mempertimbangkan aspek kelayakan teknis, kelayakan operasional, kelayakan hukum, kelayakan penjadwalan dan kelayakan ekonomi.

d. Menentukan syarat informasi dan syarat sistem

Mengidentifikasi informasi apa saja yang dibutuhkan oleh pemakai SIA dan mendokumentasikan persyaratan sistem.

e. Laporan analisis sistem Laporan ini merupakan ringkasan dan dokumentasi aktivitas analisis dan akanbermanfaat bagi para perancang sistem sebagai dasar pembuatan rancangan.

2. Perancangan Konseptual

Pada tahap ini dilakukan pengidentifikasian dan penentuan alternatif rancangan. Terdapat tiga kegiatan dalam perancangan konseptual yaitu:

a. Mengevaluasi alternatif rancangan.

b. Membuat spesifikas rancangan.

c. Membuat laporan hasil perancangan konsep.

3. Perancangan Fisik Sistem

Pada tahap ini dilakukan penjabaran lebih lanjut hasil dari rancangan konsep yang masih bersifat umum ke dalam spesifikasi yang rinci untuk membuat dan menguji program komputer. Langkah-langkah dalam perancangan fisik sistem adalah:

a. Perancangan input.

Mengidentifikasi jenis input data dan metode input yang optimal.

b. Perancangan output.

Menentukan bentuk, sifat, isi dan waktu atau saat pencetakan laporan, dokumen dan penayangan di layar monitor.

c. Perancangan file dan database.

Mempertimbangkan media, organisasi dan akses, moda pemrosesan, pemeliharaan, ukuran 
dan tingkatan dalam pembuatan file dan database.

d. Perancangan program.

Kegiatan yang digunakan untuk memperbaiki penyusunan program.

e. Perancangan prosedur.

Prosedur harus mencakup penyiapan input, pemrosesan transaksi, pendeteksian dan pembetulan kesalahan, pengawasan atau pengendalian, rekonsiliasi saldo, akses database, penyiapan dan distribusi output dan instruksi operator komputer. Pada umumnya prosedur berbentuk buku pedoman.

f. Perancangan pengawasan.

Pengawasan input, pemrosesan dan fungsi database secara tepat agar dapat menghasilkan informasi yang bernilai dan bermanfaat bagi para pemakai.

g. Pembuatan laporan hasil perancangan fisik.

Menyusun laporan rancangan fisik yang menjadi dasar atau acuan bagi manajemen apakah akan melanjutkan ke tahap implementasi atau tidak.

4. Implementasi dan Konversi

Tahap ini merupakan tahap terpenting sekaligus paling kompleks, pada tahap ini dilakukan pemasangan dan pengujian perangkat keras dan perangkat lunak serta uji coba program kepada perusahaan. Konversi merupakan proses perubahan dari sistem lama ke sistem baru. Proses tersebut dianggap selesai apabila sistem baru telah berjalan dengan semestinya.

5. Operasi dan Pemeliharaan

Merupakan tahap terakhir pada sebuah SDLC, pada tahap ini dilakukan pengoperasian dan pemeliharaan sistem baru.Guna menjamin bahwa sistem baru telah memenuhi tujuan yang direncanakan maka perlu dilakukan pengujian sebagai evaluasi dari sistem tersebut.

\section{METODE PENELITIAN \\ Jenis Data \\ Data Menurut Sifatnya}

Berdasarkan sifatnya, data yang digunakan adalah data kuantitatif dan data kualitatif

a. Data Kuantitatif

Data kuantitatif adalah data-data yang disajikan dalam bentuk angkaangka.Data kuantitatif yang digunakan adalah data persediaan, pembelian dan safety stock pada CV Media Karya.

b. Data Kualitatif

Data kualitatif adalah data-data yang disajikan dalam bentuk uraian terdiri dari kumpulan data non angka.Data kualitatif yang digunakan adalah berupa gambaran umum perusahaan, visi dan misi, lokasi dan struktur organisasi beserta tugas masing-masing bagian pada CV Media Karya.

\section{Data Menurut Sumbernya}

a. Data Primer

Data primer adalah data yang diperoleh dari tangan pertama yang berkaitan dengan variabel minat untuk tujuan spesifik studi. Data primer yang diperoleh antara lain data pembelian, data persediaan, company profile dan struktur organisasi pada CV Media Karya.

b. Data Sekunder

Data sekunder adalah data yang dikumpulkan dari sumber yang telah ada.Data diperoleh dari sumber internet, penelusuran dokumen, buku atau majalah.

\section{Metode Pengumpulan Data}

Berikut ini metode yang digunakan dalam pengumpulan data yang dibutuhkan dalam perancangan sistem:

a. Wawancara

Wawancara dilakukan secara langsung bersama direktur CV Media Karya untuk memperoleh data yang dibutuhkan dalam pembuatan aplikasi dan penyusunan laporan.Data yang 
diperoleh berupa prosedur pembelian persediaan kepada supplier.

b. Observasi

Observasi dilakukan dengan melakukan pengamatan secara langsung di tempat produksi CV Media Karya pada bulan Mei sampai dengan Juli 2018. Observasi dilakukan untuk mendapatkan informasi mengenai pembelian bahan baku, jenis bahan baku dan penggunaannya.

c. Studi Pustaka

Studi Pustaka yaitu mempelajari pustaka yang berhubungan dengan permasalahan yang dihadapi dan melalui penelitian terdahulu yang telah dilakukan.

d. Dokumentasi

Dilakukan dengan cara mengadakan pemahaman terhadap catatan-catatan atau laporan-laporan yang terkait dengan masalah yang timbul. Selain itu juga melihat bukti-bukti transaksi pembelian.Dokumen tersebut seperti data pelanggan, data pemasok/supplier data persediaan, data pembelian.

\section{Metode Penulisan}

Bentuk penulisan yang digunakan dalam penyusunan penelitian ini adalah:

\section{a. Deskripsi}

Metode penulisan ini digunakan untuk menguraikan gambaran umum objek penelitian.Gambaran umum tersebut meliputi sejarah berdirinya perusahaan, company profile, struktur organisasi serta tugas dan wewenang masing-masing bagian pada CV Media Karya.

b. Eksposisi

Metode penulisan eksposisi ini digunakan untuk memberikan penjelasan, keterangan dan informasi bahan baku, mulai dari prosedur permintaan, pembelian, pemakaian bahan baku dan jenis-jenis bahan baku yang terdapat pada CV Media Karya.

\section{ANALISIS DAN PEMBAHASAN}

\section{Kebijakan Sistem Pembelian}

Terdapat beberapa kebijakan yang diterapkan pada sistem pembelian bahan baku pad CV Media Karya, antara lain:

1. Kegiatan pembelian pada CV Media Karya dilakukan oleh pemilik atau direktur.

2. Jenis transaksi pembelian yang digunakan adalah pembelian secara kredit.

3. Semua transaksi pembelian pada CV Media Karya dilakukan berdasarkan order pembelian.

\section{Deskripsi Sistem}

Sistem pembelian bahan baku pada CV Media Karya pada umumnya dilakukan secara manual. Sistem pembelian baku digunakan untuk mengelola transaksi pembelian bahan yang digunakan pada bagian konveksi untuk memproduksi pesanan. Setiap transaksi pembelian yang terjadi dicatat dalam buku pembelian dan buku catatan persediaan.

\section{Dokumen yang Digunakan}

Dokumen yang digunakan dalam sistem pembelian bahan baku pada CV Media Karya, antara lain:

1. Daftar Order Pembelian

Daftar order pembelian merupakan daftar bahan yang akan dipesan oleh bagian gudang yang berisi mengenai persediaan yang habis atau akan habis dan akan dilakukan pembelian.

2. Faktur Pembelian

Faktur pembelian merupakan dokumen yang diperoleh dari pemasok atau supplier yang digunakan sebagai bukti telah dilakukannya transaksi pembelian bahan baku.

\section{Catatan yang Digunakan}

Catatan yang digunakan dalan sistem pembelian bahan baku pada CV Media Karya adalah sebagai berikut:

1. Buku Pembelian 
Buku pembelian ini digunakan untuk mengetahui jumlah pembelian kredit (utang) dan sebagai dasar dalam penyusunan laporan keuangan.

2. Buku Catatan Persedian

Buku ini digunakan untuk mencatat data persediaan bahan baku yang ada pada CV Media Karya.

\section{Laporan yang Dihasilkan}

Laporan yang dihasilkan oleh sistem pembelian bahan baku pada CV Media Karya adalah:
1. Laporan Pembelian

Laporan pembelian berisi informasi mengenai jumlah pembelian bahan baku pada periode tertentu.

2. Laporan Data Utang

Laporan yang berisi mengenai jumlah utang yang timbul atas suatu pembelian bahan.

3. Laporan Persediaan

Laporan yang berisi mengenai stok dan mutasi bahan baku.

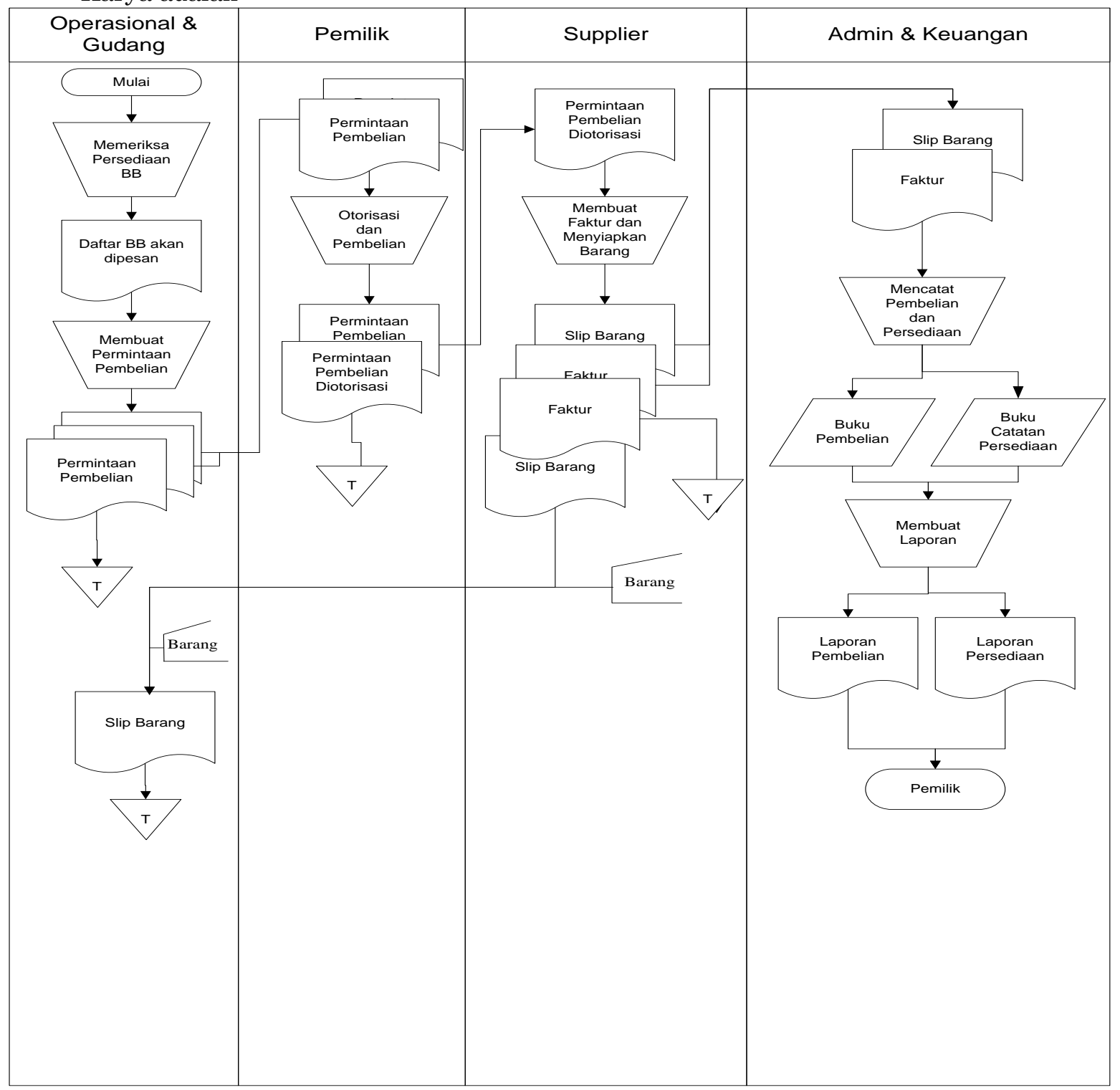

Gambar 4.1 Bagan Alir Dokumen Sistem Pembelian Bahan Baku

Sumber: Data Primer yang diolah, 2018 


\section{Perancangan}

Pada tahap ini akan dibahas mengenai penyusunan sistem informasi pembelian bahan baku terkomputerisasi pada CV Media Karya menggunakan Micosoft Visual Basic 6.0 dengan tahap system development life cycle, sebagai berikut:

\section{Analisis Sistem}

Tahap analisis sistem merupakan salah satu tahap pada System Development Life Cycle (SDLC). Dalam pembuatan sistem pembelian bahan baku diperlukan tahaptahap berikut ini:

1. Survei tehadap sistem yang digunakan Survei yang dilakukan pada CV Media Karya yaitu dengan melakukan pengamatan dan wawancara secara langsung kepada pemilik atau direktur CV Media Karya mengenai sistem pembelian bahan baku. Dari hasil survei tersebut dapat diketahui bahwa, sistem pembelian bahan baku yang digunakaan pada CV Media Karya masih menggunakan sistem berbasis manual yang menyebabkan adanya kesalahan penatatan dan lamanya tersaji laporan pembelian bahan baku.

2. Hasil dari tahap analisis

Berdasarkan hasil survei di atas maka perlu diadakannya perbaikan sistem pembelian bahan baku secara terkomputerisasi. Sistem ini dapat membantu dalam pekerjaan menjadi lebih cepat dan dapat mengurangi kesalahan yang diakibatkan oleh human error.Karena CV Media Karya merupakan perusahaan dengan sistem penjualan berbasis pesanan maka akan dibuat form untuk pemakaian bahan baku agar setiap produk pesanan terlihat dengan jelas bahan baku yang digunakan.

\section{Hasil Perancangan}

1. Menu Login

Menu login merupakan langkah awal yang dilewati ketika mulai pengoperasian program, yaitu dengan menginput username dan password. Menu ini berguna sebagai pengendalian intern terhadap hak akses program sehingga program aplikasi hanya dapat digunakan oleh orang atau bagian tertentu yang diperbolehkan.

\section{Menu Utama}

Memu utama merupakan menu yang menyajikan berbagai submenu.

3. Menu Master

Menu master merupakan menu yang menyajikan data-data master meliputi data pemasok dan bahan baku.

\section{Menu Tansaksi}

Menu transaksi berisi untuk menginput data order, transaksi pembelian dan penggunaan bahan baku.

\section{Menu Laporan}

Menu ini digunakan melihat hasil dari data yang telah dimasukkan berupa laporan, seperti laporan pembelian, laporan data pemasok, laporan mutasi persediaan.

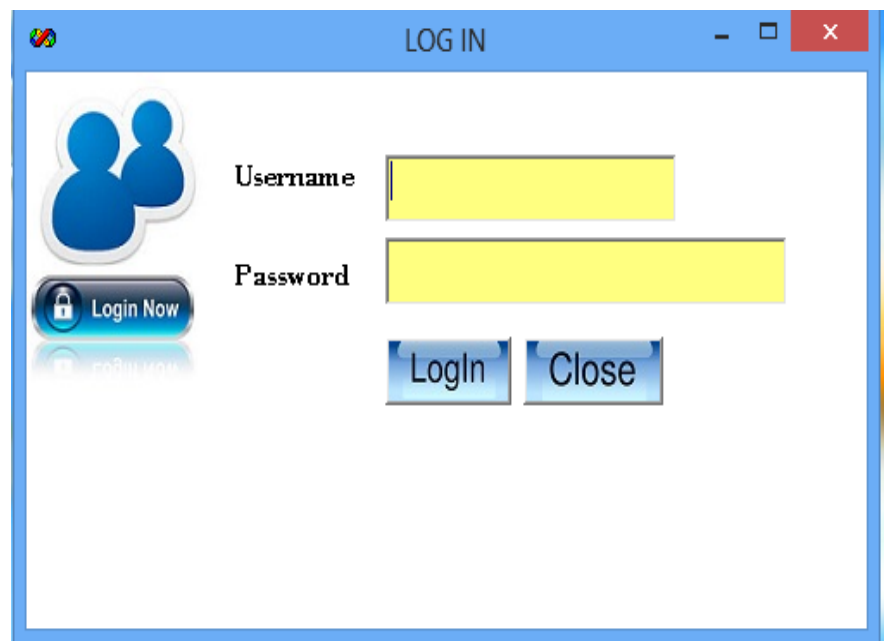

Gambar 4.2 Tampilan Form Login

Sumber: Data Primer yang diolah, 2018

Digunakan untuk melakukan login aplikasi atau masuk ke dalam aplikasi sebelum mengoperasikannya. 


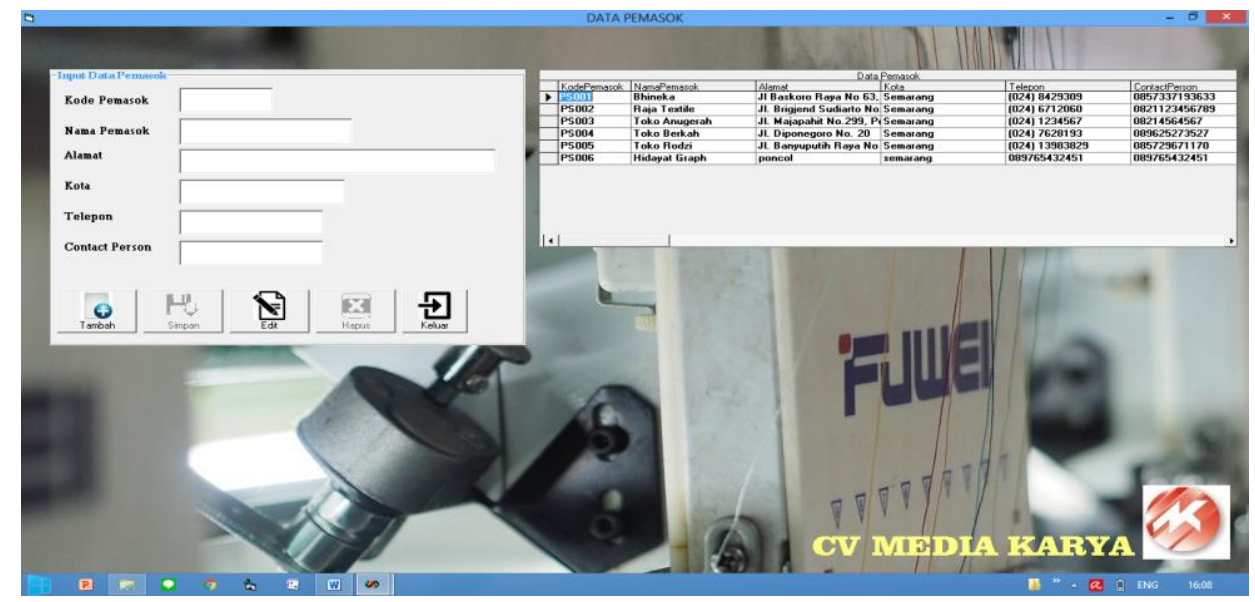

Gambar 4.3Tampilan Form Input Data Pemasok

Sumber: Data Primer yang diolah, 2018

Form di atas digunakan untuk memasukkan, menyimpan, mencari data pemasok yang memiliki hubungan dengan CV Media Karya.

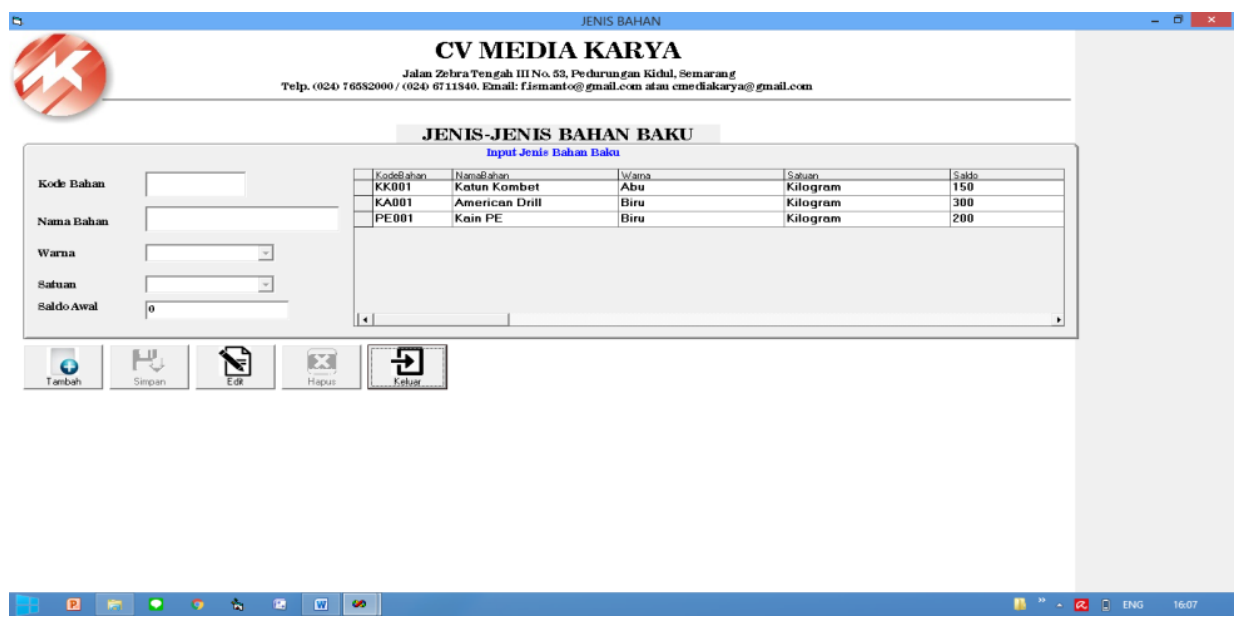

Gambar 4.4Tampilan Form Input Jenis Bahan dan Saldo Awal

Sumber: Data Primer yang diolah, 2018

Form di atas berfungsi untuk memasukkan kode bahan, nama bahan, warna dan satuan da saldo awal yang akan disimpan dalam database. 


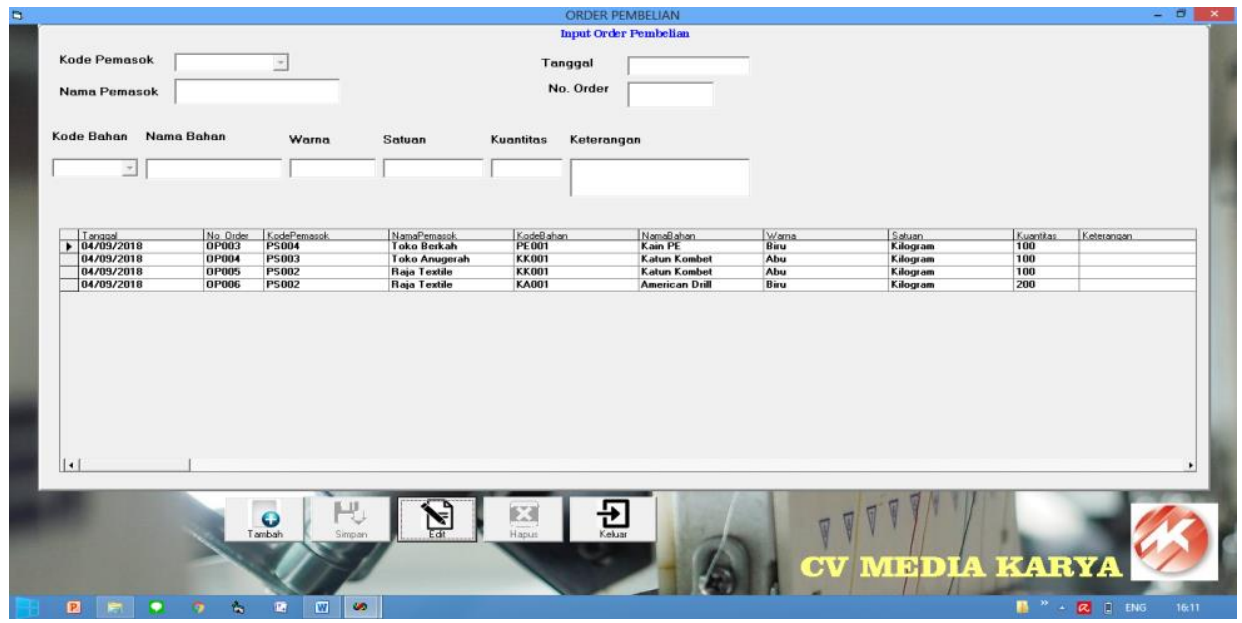

Gambar 4.5Tampilan Form Input Order Pembelian

Sumber: Data Primer yang diolah, 2018

Form di atas digunakan untuk memasukkan data transaksi order pembelian bahan baku pada CV Media Karya.

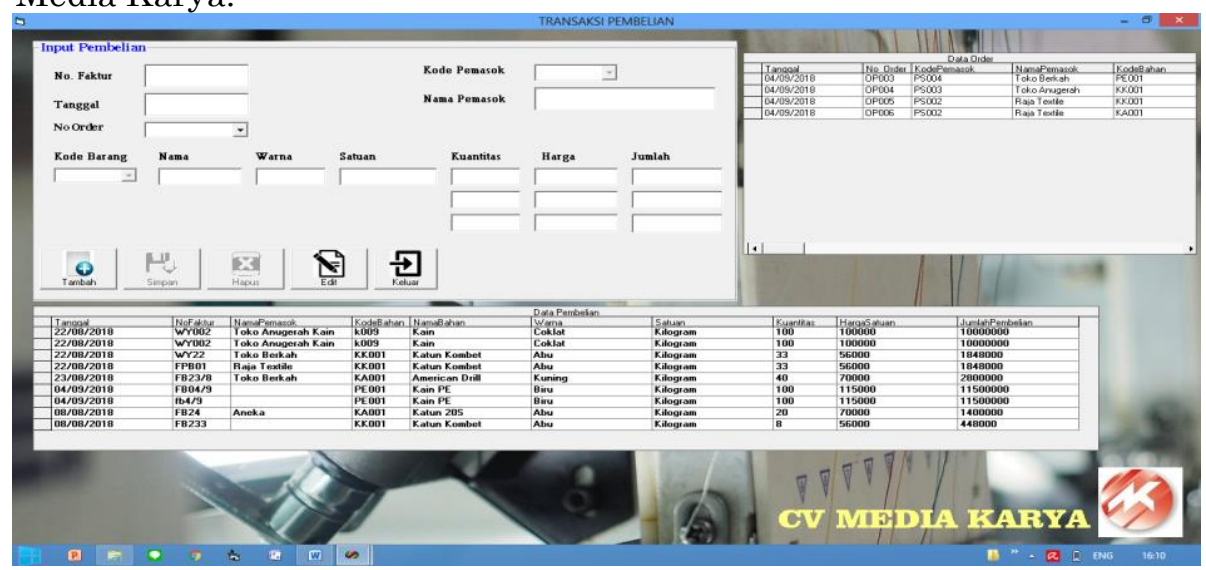

Gambar 4.6Tampilan Form Transaksi Pembelian

Sumber: Data Primer yang diolah, 2018

Form di atas digunakan untuk memasukkan data transaksi pembelian bahan baku pada CV Media Karya.

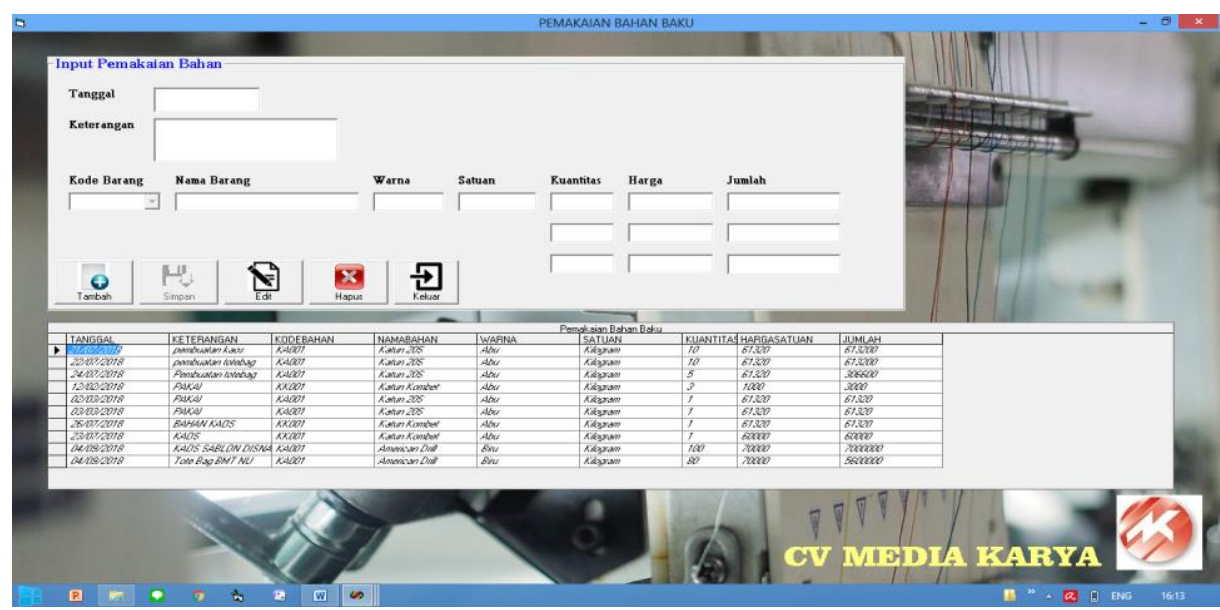




\section{Gambar 4.7Tampilan Form Pemakaian Bahan}

Sumber: Data Primer yang diolah, 2018

Form di atas digunakan untuk memasukkan data transaksi pemakaian bahan baku pada CV Media Karya.

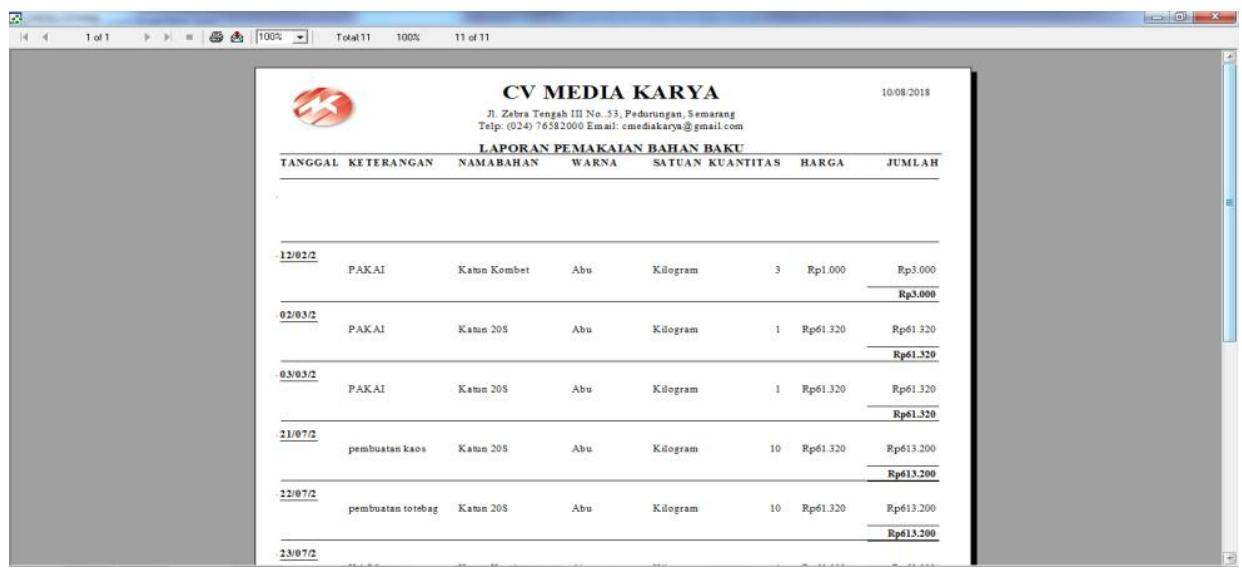

Gambar 4.8Tampilan Laporan Pemakaian Bahan

Sumber: Data Primer yang diolah, 2018

Laporan pemakaian bahan bakumemberikan informasi mengenai pemakaian bahan baku yang digunakan dalam pembuatan produk

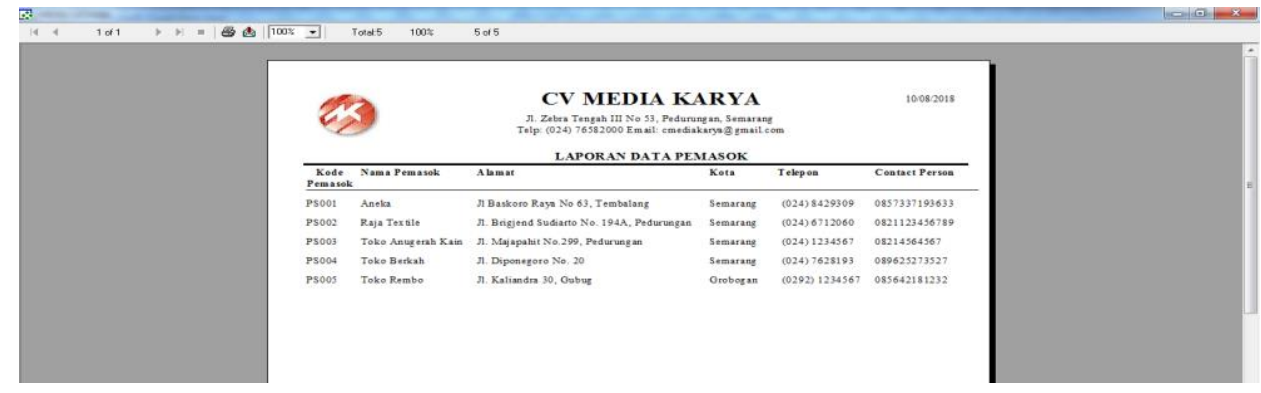

Gambar 4.9Tampilan Laporan Data Pemasok

Sumber: Data Primer yang diolah, 2018

Laporan data pemasok memberikan informasi mengenai identitas para pemasok.

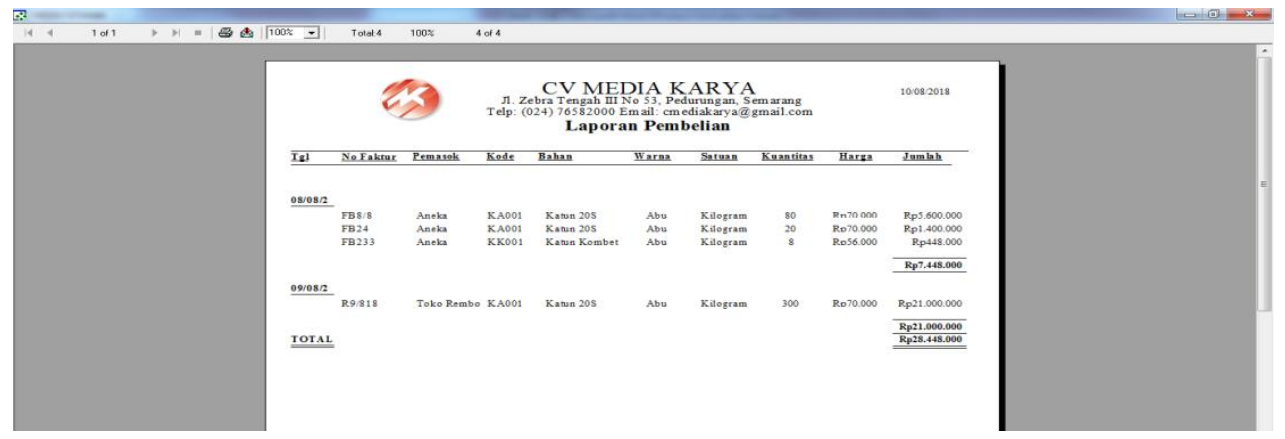

Gambar 4.10Tampilan Laporan Pembelian

Sumber: Data Primer yang diolah, 2018

Laporan pembelian dapat memberikan informasi jumlah pembelian yang terjadi pada CV Media Karya. 


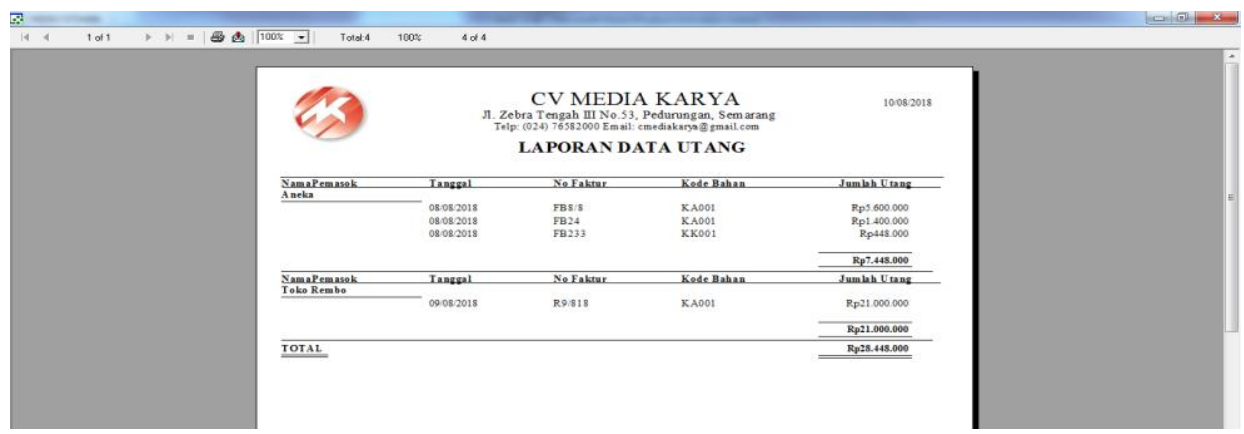

Gambar 4.11Tampilan Laporan Data Utang

Sumber: Data Primer yang diolah, 2018

Laporan data utang memberikan informasi mengenai data utang yang timbul yang diakibatkan oleh pembelian bahan baku secara kredit.

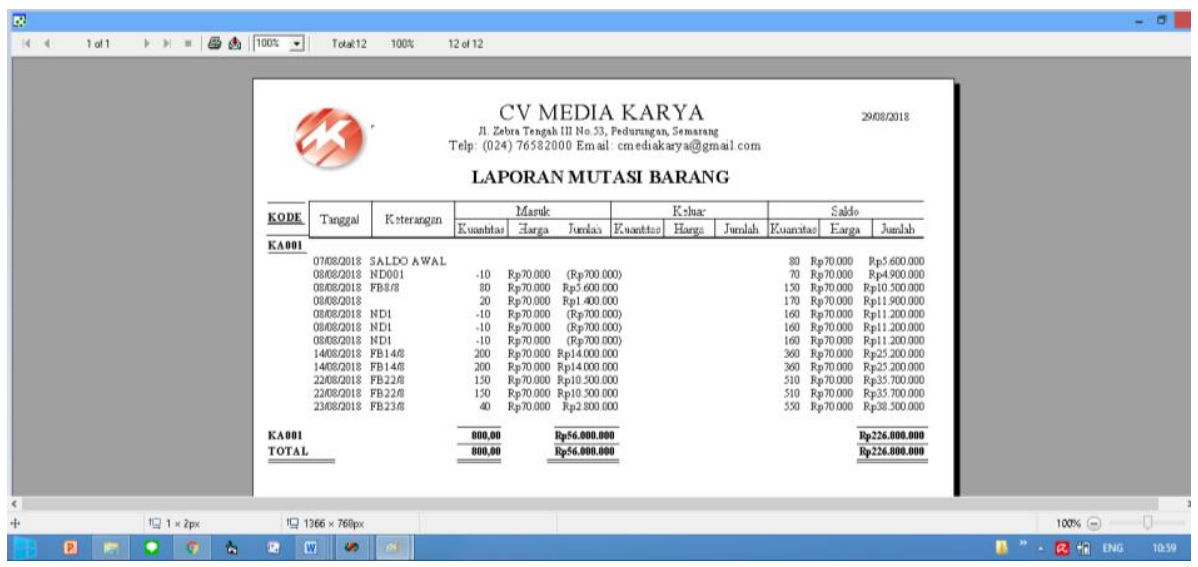

Gambar 4.12Tampilan Mutasi Barang

Sumber: Data Primer yang diolah, 2018

Laporan mutasi barang dapat memberikan informasi mengenai keluar masuknya barang berupa bahan baku setiap jenis.

\section{KESIMPULAN}

Berdasarkan analisis dan perancangan mengenai sistem informasi pembelian bahan baku pada CV Media Karya, dapat ditarik kesimpulan sebagai berikut:

1. Telah disusun sistem informasi pembelian bahan baku secara terkomputerisasi menggunakan Microsoft Visual Basic 6.0 dengan penyimpanan database pada Microsoft Acces dan desain laporan dengan menggunakan Crystal Report 8.5.

2. Laporan yang bisa dihasilkan dari sistem informasi pembelian bahan baku pada CV Media Karya yang sudah dirancang meliputi laporan data pemasok, laporan pembelian, laporan data utang, laporan pemakaian bahan baku, dan laporan mutasi persediaan.

\section{DAFTAR PUSTAKA}

Diana, Anastasia dan Setyawati, Lilis. 2011. Sistem Informasi Akuntansi "Perancangan, Proses dan Penerapan". Yogyakarta: Penerbit Andi.

Solihin,Hanan Hanhafiah. Nusa, A.A.Fuja. 2017. Rancang Bangun Sistem Informasi Penjualan, Pembelian dan Persediaan Suku Cadang pada Bengkel Tiga Putra Motor Gartut. Program Studi Sistem Informatika. Universitas Sangga Buana YPKP Bandung. 
Isroi. Ramadhan, Areif. 2004. SeriPembelajaran Komputer Microsoft Visual Basic 6.0. Jakarta: PT Elex Media Komputindo

Kementrian Keuangan Republik Indonesia.2016.UMKM Berpotensi Tingkatkan Pertumbuhan Ekonomi Indonesia. https://www.kemenkeu.go.id/publikasi/b erita/umkm-berpotensi-tingkatkanpertumbuhan-ekonomi-indonesia/. 29 Agustus 2018.

Krismiaji. 2010. Sistem Informasi Akuntansi. Yogyakarta: UPP-STIM YKPN

Mulyadi. 2016. Sistem Akuntansi. Jakarta: Salemba Empat

Puspitawati, Lilis dan Anggadini, Sri Dewi. 2011. Sistem Informasi Akuntansi. Yogyakarta: GRAHA ILMU.

Romney, Masshall B.Steinbart. Paul John.2015.Sistem Informasi Akuntansi.Jakarta: Salemba Empat.

Sekaran, Uma. 2011. Research Method For Bussiness Edisi 4. Jakarta: Salemba Empat.

TMBooks. 2015. Sistem Informasi Akuntansi. Yogyakarta: Penerbit Andi.

Widilestariningtyas, Ony. Anggadini, Sri Dewi. Firdaus, Dony Waluya. 2012. Akuntansi Biaya. Yogyakarta: Graha Ilmu. 